\title{
Investment criteria for public projects ${ }^{1}$
}

\author{
P. C. van den Noort
}

Department of Agricultural Economics, Agricultural University, Wageningen, The Netherlands

Received 27 July, 1967

\section{Summary}

Government investments are very large nowadays. So it is necessary that they are well directed. To reach this goal we need a criterion for investments. The usual criterion applied to government investments is the benefit/cost ratio. This conventional type of investment criterion can lead to investment decisions that are not in accordance with the goal of maximal growth of national product. This is a serious disadvantage of this criterion. It is necessary therefore to use another one. The optimal criterion appears to be the rate of return on capital invested in government projects.

\section{The problem}

Government investments are very large nowadays. It is important therefore that they are well directed. To reach this goal and to cheque these governmental activities it is desirable to develop a criterion for these investments. Several criteria have been proposed: the difficulty, however, is that they all lead to different conclusions. Let us take for example the case that the total amount of government investments in a certain sector of the economy has been set. The object of this investment is to improve national income. Several projects (plans) are on the list. It is not possible to carry out all of these plans, so it will be necessary to make a ranking in order to decide which plans we shall carry out and which not. Some facts about these (five) projects, which are all of the same type (e.g. landreclamation, irrigation or dams with hydroelectric power stations) are given in Table 1.

Which plan has the highest priority and what is the optimal sequence for carrying out the other plans? There are quite different proposals, depending on the criterion used. According to these criteria that project is set on the first place that

1) has the largest difference between benefits and cost;

2) has the highest benefits per unit of the cost, or in other words has the highest benefit/cost ratio;

3) has the highest benefit/capital ratio;

4) will give the highest return on the capital invested.

Let us apply these criteria on the five projects of Table 1 ; the results are given in Table 2.

The difficulty for the decision making authority is obvious, for very different se-

1 Already published in Dutch in a slightly different form in Landbouwkundig Tijdschrift, 78 (1966) : 306-311. 
Table 1 Economic data of the five projects ( $m l n$ dollars)*

\begin{tabular}{lllllll}
\hline & & \multicolumn{7}{c}{ Projects } \\
\cline { 3 - 7 } & & $A$ & $B$ & $C$ & $D$ & $E$ \\
Capital needed & $\mathrm{K}$ & 20 & 20 & 20 & 25 & 30 \\
Annual benefits & $\mathrm{B}_{\mathrm{t}}$ & 1.5 & 2.0 & 2.5 & 2.5 & 3.55 \\
Total annual cost & $\mathrm{C}$ & 0.9 & 1.2 & 1.3 & 1.7 & 2.3 \\
\hline
\end{tabular}

* $\mathrm{B}_{\mathrm{c}}$ and $\mathrm{C}_{\mathrm{t}}$ are constant in time. The cost comprises also risk and interest (market rate of interest 5 per cent). The amortization-period of the five projects is the same.

Table 2 Ranking of the projects of table 1 according to the different criteria

\begin{tabular}{ccccc}
\hline Rank & \multicolumn{5}{c}{ Criteria } \\
& (I) & $(2)$ & $(3)$ & $(4)$ \\
& & & & \\
1 & E & A, B & E & A \\
2 & B, D & C, E & B, C, D & B \\
3 & C & D & A & C \\
4 & A & & & D \\
5 & & & & E \\
\hline
\end{tabular}

quences or rankings are defensible; it is possible for example to take project $A$ first or last.

What is the relevant investment criterion? This is a difficult problem for economic analysis not only in capitalistic economies, but also in the Soviet economy (Yevenko, 1965). In the capitalistic world the problem not only plays a role within each country, but also in the proces of economic integration of nations. Some economists argue that during this proces participating nations should prepare the investments plans and a central agency should coordinate these plans. At the same time, according to Balassa (1962), others contend that in the absence of an "unequivocal, objective and quantitatively definable" criterion the central planning of investments would give a solution greatly inferior to that attainable without government interference.

\section{Government investments and economic development}

Let us suppose that the objective of economic policy is to maximine national product (per head of population). It is possible to get a higher national product by economic development. The essence of economic development is, according to Schumpeter (1961), to give a better employment to existing services of labor and land (= natural resources). To get a better employment of labour and land it often will be necessary to withdraw these factors from their present occupation. In our type of economy this can be reached by the aid of 'capital'. Capital in this context is an amount of purchasing power by which we can attrack all kinds of concrete means of production (Ashby, 1961; Schumpeter, 1961). 
Government is well suited to bring about some better combinations of labour and land, or in other words to bring about some innovations. In doing so, government will stimulate economic development. For carrying out these innovations a certain amount of 'capital' will be needed. A lot of labour and land will be used then in order to create for example the machines, roads and buildings of which the project consists. We can also say that a part of national income will be used for the construction of the 'project', a thing that does not produce income already itself. It is hoped, however, that it will produce an income in the future. If it has been decided to carry out the project we can say that the expected or 'future income' is preferred to the 'present income'. How can that be? Simply because it is hoped (expected, estimated) that this future income will be higher than the present income.

We prefer that policy by which this growth of income is the most rapid. If there are different projects, we must choose those projects which will give the highest future income in comparison to the income (I) used at this moment for their construction. Suppose a project will give an income $\mathrm{Y}_{\mathrm{t}}$ at any moment $t$; we define $r$ :

$$
\sum_{t=1}^{T} \frac{Y_{t}}{(1+r)^{t}}=I
$$

We can estimate $r$ for all government projects proposed. The higher $r$ the better the project is suited to our objective, because the higher $r$ the higher is the stream of future income in comparison to the income we invest in the project now. This income invested in the project can be called 'capital' and then $r$ can be identified with the rate of return on capital invested in projects.

So it follows that the investmentcriterion that suits best to our objective is the rate of return on capital. This conclusion is well in accordance with the newest theory of Harrod (1964), about growth and investment, but others prefer the benefit/cost ratio, which generally speaking, gives different results ${ }^{2}$. Let us investigate this preference.

\section{The basis of the use of the Benefit/Cost ratio as investment criterion}

By means of taxation it is possible to the government to withdraw purchasing power from the public. A part of tax revenue can be used for investments. So this part has the function of capital. This capital is available in very large amounts, but only at increasing costs because it must be withdrawn from other government expenditures respectively from the public.

The question is: How far can government go with these investments? Eckstein (1965) has analysed this question in a rather abstract, mathematical way. In this analysis their are two pivots: the utility function of the consumers and the productionfunction of the project. If the project comes in operation some factors of production are converted into goods, according to the production-function of the project. This productionproces has two sides: benefits and costs. The benefits consist of the utility of the new goods, and the costs of the utility of the goods that cannot be produced

2 There is a lot of discussion in this field : Darișson, 1964; Eckstein, 1965; Prest \& Turvey, 1965; Van den Noort, 1966. 
now, because the factors are withdrawn from other opportunities. There is an increase in national income as long as the benefits are higher than the costs. Government can go to the maximum real income; this is reached at the point where marginal benefit equals marginal cost, or where the benefit/cost ratio is 1.0 .

In case government expenditures are limited we cannot reach this point. Then, according to Eckstein, we have to give priority to the project with the highest benefit/ cost ratio: "if, in each year, those projects are started, which have the highest benefit/cost ratios (...) then the total return on federal expenditures will be maximized". To this opinion national welfare reaches also a maximum. In the Dutch literature about government projects especially of landreclamation in the Zuydersea the same opinions can be found (Glinstra Bleeker, 1954; Tinbergen, 1958).

According to these opinions top priority should be given to project $A$ or $B$ in Table 1, after these come the projects $D$ or $E$ and project $C$ is the last one. So project $A$ is preferred to $C$, but it is obvious that $C$ gives a greater contribution to national products than project $A$, whereas the same investment is necessary. Now Eckstein also intends to reach on maximal change in real income with the aid of these government investments; here is a contradiction. This difficulty arises out of the calculation of the interestcosts in the American examples of Eckstein (1965) and the examples of Glinstra Bleeker (1954) and Tinbergen (1958) for the Netherlands. The calculation of the interestcosts is, correctly, based on the principle of opportunity costs. What rate of interest do we have to use then in this calculation? Eckstein says: "This rate can only be estimated by tracing the capital to its source and by discovering its value in the use to which it would be put in the absence of the public project". Perhaps it is not so easy to find this rate of interest, but suppose it is $\mathrm{i} \%$. This is the rate of interest used by Eckstein and Glinstra Bleeker in their benefit/cost calculations, intended to give the right economic priority to plans and projects. So, according to their analysis, the alternative for investment in a certain project (say project $\mathbf{A}$ of Table 1) is 'not to invest'.

But this clearly is not true because there are many other possibilities open, namely all other plans of public projects (including alternative plans for project $\mathrm{A}$ ).

As a matter of fact there are two problems instead of only one:

a) do we have to invest in the private or in the public sector?

b) if the last opportunity is chosen which government project do we choose first and what is the optimal sequence for carrying out further investments?

The decision about (a) depends on the fact whether private return on capital is higher or not than in government projects. In comparing both types of investment it is only logical to use in the calculations the rate of interest $i$, as defined by Eckstein. If the cost of government projects estimated with the aid of this rate of interest exceed the benefits then it is no wise policy to take purchasing power out of the private sector in order to invest it in public projects. These rate of interest, however, cannot be used to arrive at an decision on the second problem of choice. Here the problem is not public or private use of the purchasing power, but in which project must we invest in order to get the highest future income, or the highest rate of growth? We saw already that this would be the case if $r$ is as large as possible.

I think using the highest rate of return on capital as the opportunity cost for capital will also give the right decision in using the benefit/cost ratio as investment criterion. This can be proved in the following way.

Total cost in any year $t$ is called $C_{t}$. These costs consist of two parts: an annuity 
and other costs, $\mathrm{O}_{t}$. The annuity is equal to $\mathrm{a}_{\mathrm{iT}} \mathbf{K}$, in which $\mathrm{a}_{\mathrm{iT}}$ is the amortizationfactor for $\mathrm{i}$ per cent of interest and an amortization period of $\mathrm{T}$ years and $\mathrm{K}$ is the amount of capital needed. The sum of present values of all 'other costs $\mathrm{O}_{t}$ ' is called $O$. We can say $O=O_{t} / a_{i T}$.

The benefits in any year $t$ are $B_{t}$. Now these benefits are equal to the sum of $\mathrm{O}_{\mathrm{t}}$, the depreciation of capitalgoods and the net return on capital. Depreciation plus the net return on capital are equal to $a_{r T} K$, in which $a_{r T}$ is the amortization factor for $\mathrm{r}$ per cent of interest and an amortization period of $\mathrm{T}$ years. So we get:

$\mathrm{C}_{\mathrm{t}}=\mathrm{a}_{\mathrm{i} T} \mathrm{~K}+\mathrm{O}_{\mathrm{t}}=\mathrm{a}_{\mathrm{iT}} \mathrm{K}+\mathrm{a}_{\mathrm{iT}} \mathrm{O}$

$\mathbf{B}_{\mathrm{t}}=\mathrm{a}_{\mathrm{r} \mathrm{T}} \mathrm{K}+\mathrm{O}_{\mathrm{t}}=\mathrm{a}_{\mathrm{rT}} \mathrm{K}+\mathrm{a}_{\mathrm{iT}} \mathrm{O}$

It is easy to give a formula for the benefit/cost ratio $\beta$ :

$\beta=\frac{\mathrm{a}_{\mathrm{r} T} \mathrm{~K}+\mathrm{a}_{\mathrm{iT}} \mathrm{O}}{\mathrm{a}_{\mathrm{iT}} \mathrm{K}+\mathrm{a}_{\mathrm{iT}} \mathrm{O}}$

Now we take for $\mathrm{i}$ not the market rate of interest, as defined by Eckstein, but the highest rate of return on capital invested in public projects. We call this maximal return $\mathbf{R}$. For the project with the highest return on capital $r$ and $i$ will be equal to $R$; so $a_{i T}=a_{r T}=a_{R T} \quad$ or

$\beta=\frac{\mathrm{a}_{\mathrm{RT}} \mathrm{K}+\mathbf{a}_{\mathrm{RT}} \mathrm{O}}{\mathrm{a}_{\mathrm{RT}} \mathrm{K}+\mathbf{a}_{\mathrm{RT}} \mathrm{O}}=1$

For projects with a lower return on capital $(=$ all other projects $)$ it necessary follows: $a_{r T}<a_{R T}=a_{i T}$, so that their benefit/cost ratio $\beta^{\prime}$ is

$\beta^{\prime}=\frac{a_{\mathrm{rT}} \mathrm{K}+\mathrm{a}_{\mathrm{RT}} \mathrm{O}}{\mathrm{a}_{\mathrm{RT}} \mathrm{K}+\mathrm{a}_{\mathrm{RT}} \mathrm{O}}<1$

We may conclude that in this case the project with the highest return on capital has also the highest benefit/cost ratio. With both criteria we arrive at the same conclusion.

So the preference to use the conventional benefit/cost ratio as investmentcriterion is based on the preference to calculate the cost of capital with the aid of the rate of interest $i$ as defined by Eckstein, instead of with the aid of the highest return on capital. Is this preference warranted?

\section{The preference of $i$ is unwarranted}

The goal of the investment policy is to get an optimal growth of national product. So our investment criterion must lead to decisions which are in accordance with this goal. We saw already that the use of $r$ is in accordance with the goal of maximal economic growth (Harrod, 1964). Now in the conventional benefit/cost criterion we use $i$ instead of $r$.

This can lead us to investment decisions which are not in accordance with the goal of maximal growth. Because from formula 1 it follows that the project with the highest rate of return on capital $(=r)$ does not necessary have the highest $\beta$. This 
Table 3 Benefit/cost ratios and the rate of return on capital based on data of Glinstra Bleeker (1954)

\begin{tabular}{|c|c|c|c|c|c|}
\hline \multirow[b]{3}{*}{ Data (in mln guilders) : } & \multicolumn{5}{|c|}{ Projects } \\
\hline & $I$ & II & III & $I V$ & $V$ \\
\hline & & & & & \\
\hline capital needed & 2 & 2 & 2 & 2 & 2 \\
\hline annual benefits & 1.12 & 2.20 & 3.27 & 6.30 & 9.40 \\
\hline annual costs * & 1.00 & 2.00 & 3.00 & 6.00 & 9.00 \\
\hline Increment of national product & 0.12 & 0.20 & 0.27 & 0.30 & 0.40 \\
\hline Ranking according to: & & & & & \\
\hline Eckstein's criterion & 1 & 2 & 3 & 4 & 5 \\
\hline Rate of return on capital & 5 & 4 & 3 & 2 & 1 \\
\hline
\end{tabular}

* Including risk and interest cost $(i=5$ per cent).

project will have the highest $a_{t} T$, but an other project with a lower $a_{\mathrm{r} T}$ can have a higher $\beta$, simply if its $\mathrm{O} / \mathrm{K}$-ratio is higher. We can demonstrate this also with a numerical example, see Table 3.

We get a different ranking according to both criteria, they are even completely opposites.

The best project will be that one which gives the highest increment of national product. Now this increment is the difference between the annual benefits and the annual costs. According to Eckstein's benefit/cost ratio the best project would be project $\mathrm{I}$. This project, however, does not give the highest increment of national product. Project $\mathrm{V}$ does give an higher increment than project $\mathrm{I}$, and the investments are equal for both projects. Given the goal of investment policy project $\mathrm{V}$ must be preferred to project I. Eckstein criterion leads to a wrong decision in this case. Only in special cases it is possible that this conventional benefit/cost-criterion does not lead to such wrong decisions namely as $\mathrm{O} / \mathrm{K}=$ nihil or a constant $\mathrm{c}$ for all the plans or projects proposed, because then

$\beta=\frac{a_{\mathbf{r T}}+a_{i T} \mathrm{O} / \mathrm{K}}{a_{\mathrm{iT}}+\mathrm{a}_{\mathrm{iT}} \mathrm{O} / \mathrm{K}}=\frac{\mathbf{a}_{\mathrm{rT}}+\mathbf{a}_{\mathrm{iT}} \mathrm{c}}{\mathrm{a}_{\mathrm{iT}}+\mathrm{a}_{\mathrm{iT}} \mathrm{c}}$

whereas $a_{i T}$ is a constant, $\beta$ is proportional to $a_{\mathrm{rT}}$ or a linear function of $a_{\mathrm{r} T}$. The higher $\mathrm{r}$ the higher $\beta$ and reversed. This, however, are exceptional situations.

\section{References}

Ashby, A. W., 1961. Agricultural Economists and the Return on Capital. The Farm Economist: 509. Balassa, B., 1962. The Theory of Economic Integration, London.

Davisson, W., 1964. Public investment Criteria, Land Economics: 1953-1962. (commentaries on this article see Land Economics, 1966: 532-542).

Eckstein, O., 1965. Water resource development - The economics of Evaluation, Harvard Univ. Press.

Glinstra Bleeker, R. J. P. van, 1954. Prioriteitsbepaling van overheidsinvesteringen. De Economist (Amsterdam): 823-824.

Grossman, G., 1961. Suggestions for a Theory of Soviet Investment Planning, in: Investment Criteria and Economic Growth, M.I.T. 
Harrod, R., 1964. Optimum Investment for Growth, in: Problems Economic Dynamics and Planning (Essay in honour of Michael Kalecki), Warszawa.

Landbouwinvesteringscommissie, 1960. An Assessment of Investments in Land Reclamation, Wageningen. Publication no. 7 of the International Institute of Land Reclamation and Improvement, Wageningen.

Noort, P. C. van den, 1966. Investeringscriteria voor overheidsprojecten. Landbouwkundig Tijdschrift, 78: 306-311.

Noort, P. C. van den, 1967. Het criterium voor het vaststellen van investeringsprioriteiten van overheidsprojecten. Econ.-Stat. Berichten, 2586: 340-343.

Prest, A. R. and Turvey, R., 1965. Cost-Benefit Analysis: A survey. The Economic Journal, 75 : $683-735$.

Schumpeter, J. A., 1961. The Theory of Economic Development. Oxford Univ. Press.

Rogers, W. B., Manning, T. W. and Grubb, H. W., 1966. The economic benefits and costs of irrigation in the Eastern Irrigation District of Alberta. University of Alberta, Research Bull.

Tinbergen, J., 1958. The Design of Development, Baltimore.

Tinbergen, J., 1961. The Relevance of Theoretical Criteria in the Selection of Investment Plans in: Investment Criteria and Economic Growth, Center for International Studies M.I.T.

Yevenko, I. A., 1965. Planning in the USSR. Moscow. 